\title{
OBITUARY
}

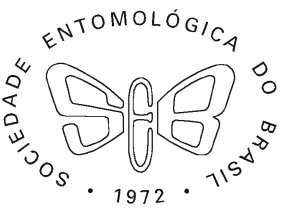

\section{Carl W. Schaefer}

(September 06, 1934 - April 29, 2015)
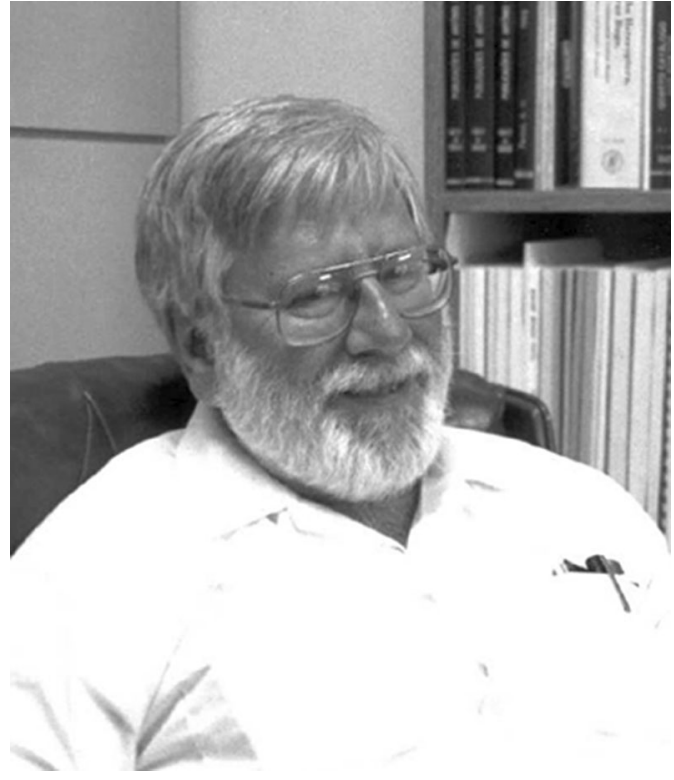

Prof. Carl Walter Schaefer II passed away on April 29, 2015 at the age of 80 after a long battle with cancer. Carl earned his B.Sc. in Zoology from Oberlin College and his PhD in Entomology from the University of Connecticut (UConn) in 1964. He was married to Stephanie Deans in 1964 and divorced in 1978. They had one daughter, Madelyn Schaefer and one stepdaughter Ann Schaefer Harlan. He had seven grandchildren and six great-grandchildren.

Carl started his teaching career in 1963 at Brooklyn College in New York, and from 1966 until his retirement in 2009 he taught several disciplines related to Entomology at UConn in the Department of Ecology and Evolutionary Biology. He attained the title of full professor in 1976.

Carl trained several MSc and PhD students on several aspects of the Heteroptera (true bugs) biology, ecology and, mostly, taxonomy. He was a very prolific author having published over 200 peer reviewed articles, dozens of book chapters, and several short articles and notes. He was also an outstanding editor, having edited or co-edited seven books.
In 1973 he began the Heteropterists' Newsletter which he edited and spread for 20 years. From 1973 to 1999 he served as the main editor of the Annals of the Entomological Society of America. In 1996 he was elected Honorary Member and in 2006 Fellow of the Entomological Society of America.

He visited several countries as an invited speaker and/or consultant. In the neotropics, Brazil was the country he visited most (at least 7 times) from the mid-9o's to the year 2006. He attended several Brazilian Congresses of Entomology as an invited speaker and/or as symposium co-organizer, and actively contributed with members of our Society. He also helped to increase the scientific reputation of the former Annals of the Entomological Society of Brazil, currently Neotropical Entomology. In 1997 at the XVI Brazilian Congress of Entomology in Salvador, Bahia he participated in a round table on editing scientific journals. He served the journal as a member of the International Editorial Board from 2001 until his death. In Brazil, Carl met lots of people, made friends, and visited several parts of the country, including the Pantanal/Amazon area.

Carl was extremely well read. He was a book collector and was familiar to the works of several famous authors in particular Charles Dickens. He liked music a lot, having played the viola in a string quartet and had a penchant for musical composition. He also was very active in his town, Mansfield Center, where he was a member of the town council and of the Mansfield Historical Society. He was also active in the American Association of University Professors.

For those who had the privilege to know and to interact with Carl Schaefer will remember him, not only as a great scientist and editor, but also as an entertainer, as a pleasant person and, most of all, as a great man.

\section{Antônio R. Panizzi}

Former SEB President

Former EiC Neotropical Entomology

Embrapa, Passo Fundo, RS, Brazil

antonio.panizzi@embrapa.br 